\title{
Changes in circulating red cell volume during the first 6 weeks of life in very-low-birth-weight infants
}

\author{
Edward F. Bell', Claude Nahmias ${ }^{2}$, John C. Sinclair ${ }^{3,4}$ and Alvin Zipursky ${ }^{5}$
}

BACKGROUND: Little is known about the change in circulating red cell volume (RCV) of very-low-birth-weight (VLBW) infants during the first weeks of life.

METHODS: RCV was measured during the first $5 \mathrm{~d}$ in 35 VLBW infants using chromium-51 labeling of the infants' red blood cells (RBCs). RCV was measured again at 6 wk of age in 12 infants, and the volumes of RBCs lost by phlebotomy and those gained by transfusion were recorded between the RCV measurements. In six infants, the volume of waste blood on materials contaminated with blood during phlebotomy, which would usually be discarded, was measured by radioactive counting.

RESULTS: The mean RCV in the first several days of life was $39.6 \mathrm{ml}(35.7 \mathrm{ml} / \mathrm{kg}$; range: $20.1-58.7 \mathrm{ml} / \mathrm{kg})$. Of the 12 infants whose RCV was measured twice, all but one had a decrease in absolute RCV. The mean RCV initially and at 6 wk were 37.3 and $26.6 \mathrm{ml}$, respectively. The mean volume of RBCs lost through phlebotomy was $29.2 \mathrm{ml}$, and the mean volume of RBCs given by transfusion was $34.5 \mathrm{ml}$.

CONCLUSION: During the first 6 wk of life, when the anemia of prematurity is evolving, the RCV falls despite complete replacement of RBCs lost by diagnostic phlebotomy with transfused RBCs.

$\mathbf{T}$ he circulating red cell volume (RCV) was first measured in newborn infants by Mollison et al. (1) in 1950 using phosphorus-32 $\left({ }^{32} \mathrm{P}\right)$. Others have subsequently reported their experiences measuring RCV directly using chromium-51 $\left({ }^{51} \mathrm{Cr}\right)(2-6)$, chromium-50 $\left({ }^{50} \mathrm{Cr}\right)(7)$, technitium-99 $\left({ }^{99} \mathrm{Tc}\right)$ (8), and biotin (9-11) as red blood cell (RBC) labels. In addition, several other methods have been used to calculate RCV based on changes in fetal hemoglobin concentration (12-14) or mismatched RBC antigens $(14,15)$ following a transfusion of packed RBCs, or by calculation from measured plasma volume and hematocrit (16).

Faxelius et al. (7) measured RCV in newborn infants, including some very-low-birth-weight (VLBW) infants, using ${ }^{50} \mathrm{Cr}$ labeling, which requires ex vivo neutron activation analysis. Their studies did not include repeated measurements of RCV in the same patients. Bratteby (5) measured RCV repeatedly on several occasions in a group of 15 infants; 8 of these infants were preterm, but none weighed less than $1.5 \mathrm{~kg}$ at birth. Serial determination of RCV during the first weeks of life in VLBW infants might shed light on the anemia of prematurity.

Little is known about the role of changing RCV in the evolution of anemia of prematurity. The study reported here was undertaken to measure the circulating RCV in a group of VLBW infants during the first few days of life and, in some of these infants, again at $6 \mathrm{wk}$ of age.

\section{RESULTS}

RCV measurements were performed during the first $5 \mathrm{~d}$ of life in 35 infants who weighed less than $1.5 \mathrm{~kg}$ at birth. Their mean birth weight was $1.10 \mathrm{~kg}$ (range: $0.60-1.45 \mathrm{~kg}$ ), and their mean gestational age was $29 \mathrm{wk}$ (range: $25-34 \mathrm{wk}$ ). The median age at the time of the initial RCV measurement was $36 \mathrm{~h} ; 30$ of the 35 infants were less than $72 \mathrm{~h}$ old. The mean RCV at initial measurement was $39.6 \mathrm{ml}$ (SD: $15.4 \mathrm{ml}$; range: $14.3-75.2 \mathrm{ml}$ ), and when expressed per kilogram body weight, it was $35.7 \mathrm{ml} / \mathrm{kg}$ (SD: $9.4 \mathrm{ml} / \mathrm{kg}$; range: $20.1-58.7 \mathrm{ml} / \mathrm{kg}$ ) (Table 1 ).

In 12 infants, the RCV was measured again at $6 \mathrm{wk}$ of age (Table 2). The mean RCV for these infants fell from $37.3 \mathrm{ml}$ (SD: $11.4 \mathrm{ml}$ ) in the first $5 \mathrm{~d}$ of life to $26.6 \mathrm{ml}$ (SD: $7.1 \mathrm{ml}$ ) at $6 \mathrm{wk}$ of age $(P<0.01)$. When expressed as $\mathrm{ml} / \mathrm{kg}$, the RCV fell from $37.3 \mathrm{ml} /$ $\mathrm{kg}$ (SD: $9.5 \mathrm{ml} / \mathrm{kg}$ ) to $21.6 \mathrm{ml} / \mathrm{kg}$ (SD: $6.0 \mathrm{ml} / \mathrm{kg}$ ). The RCV (in $\mathrm{ml}$ ) fell in 11 of 12 patients and increased in 1 patient. The mean volume of RBCs removed for laboratory analysis was $29.2 \mathrm{ml}$ (SD: $13.2 \mathrm{ml}$ ), and the volume of RBCs given by transfusion was $34.5 \mathrm{ml}$ (SD: $25.9 \mathrm{ml}$ ). The mean net RBC production (P-D) was $-15.9 \mathrm{ml}$ (SD: $18.7 \mathrm{ml}$ ), which means that $\mathrm{RBC}$ production was not sufficient to keep up with endogenous destruction. All infants except one had negative values for P-D. However, that infant had a negative value when the RBC gains and losses from an exchange transfusion were included in the calculation.

For the six infants in whom the quantity of waste blood loss was assessed by counting of radioactivity, the mean measured phlebotomy loss for laboratory analyses was $0.81 \mathrm{ml}$ of RBCs per kg per day, and the normally occult, waste loss averaged $0.08 \mathrm{ml} / \mathrm{kg} / \mathrm{d}$, or an additional $10 \%$ above the measured phlebotomy loss. 
Articles | Bell et al.

Table 1. Circulating RCV in the first $5 \mathrm{~d}$ of life in VLBW infants

\begin{tabular}{|c|c|c|c|c|c|c|c|}
\hline Patient number & Birth weight (g) & Gestational age (wk) & Age at study (d) & Weight at study (kg) & $\mathrm{RCV}(\mathrm{ml})$ & $\mathrm{RCV}(\mathrm{ml} / \mathrm{kg})$ & Hct (\%) \\
\hline 1 & 1,120 & 29 & 5 & 0.99 & 24.0 & 24.2 & 52 \\
\hline 2 & 720 & 25 & 0 & 0.72 & 28.0 & 38.9 & 57 \\
\hline 4 & 1,315 & 27 & 2 & 1.31 & 61.4 & 46.8 & 59 \\
\hline 5 & 1,100 & 27 & 3 & 1.09 & 44.6 & 40.8 & 38 \\
\hline 7 & 980 & Unknown & 0 & 1.00 & 36.0 & 36.0 & 70 \\
\hline 8 & 780 & 29 & 2 & 0.78 & 45.8 & 58.7 & 66 \\
\hline 9 & 960 & 28 & 1 & 0.96 & 26.1 & 27.2 & 43 \\
\hline 10 & 920 & 26 & 0 & 0.92 & 36.2 & 39.3 & 50 \\
\hline 11 & 950 & 32 & 5 & 0.92 & 28.0 & 30.5 & 59 \\
\hline 15 & 1,180 & 33 & 2 & 1.18 & 36.2 & 30.7 & 38 \\
\hline 16 & 680 & 27 & 4 & 0.68 & 14.3 & 22.5 & 46 \\
\hline 17 & 1,170 & 27 & 2 & 1.20 & 48.8 & 40.7 & 65 \\
\hline 18 & 1,070 & 28 & 3 & 1.07 & 40.8 & 38.1 & 61 \\
\hline 19 & 960 & 27 & 2 & 0.94 & 31.0 & 33.0 & 48 \\
\hline 20 & 1,400 & 32 & 1 & 1.40 & 72.2 & 51.5 & 69 \\
\hline 21 & 1,140 & 27 & 1 & 1.14 & 38.0 & 33.3 & 49 \\
\hline 22 & 600 & Unknown & 5 & 0.60 & 15.7 & 26.2 & 37 \\
\hline 29 & 1,380 & 32 & 2 & 1.38 & 47.6 & 34.5 & 54 \\
\hline 30 & 1,240 & 32 & 2 & 1.30 & 30.1 & 23.1 & 38 \\
\hline 31 & 1,370 & 34 & 3 & 1.41 & 74.8 & 53.7 & 72 \\
\hline 32 & 850 & 25 & 2 & 0.82 & 24.7 & 30.2 & 48 \\
\hline 33 & 960 & 26 & 1 & 0.94 & 35.4 & 37.6 & 46 \\
\hline 34 & 1,170 & 29 & 3 & 1.13 & 37.1 & 32.8 & NA \\
\hline 35 & 685 & 27 & 1 & 0.68 & 24.7 & 36.4 & NA \\
\hline Mean & 1,102 & 28.9 & - & 1.10 & 39.6 & 35.7 & - \\
\hline SD & 230 & 2.6 & - & 0.23 & 15.4 & 9.4 & - \\
\hline
\end{tabular}

Hct, hematocrit; NA, not available; RCV, red cell volume; VLBW, very low birth weight.

\section{DISCUSSION}

The mean RCV in our patients, $35.7 \mathrm{ml} / \mathrm{kg}$ soon after birth and $21.6 \mathrm{ml} / \mathrm{kg}$ at $6 \mathrm{wk}$, is similar to the results previously reported for newborn infants $(1,4,5,7,8,10,11)$.

Bratteby (5) demonstrated a fall in RCV expressed in $\mathrm{ml} /$ $\mathrm{kg}$ during the first several months in a group of patients that included eight preterm infants, all with higher birth weights than our study infants. Our results demonstrate the same phenomenon in VLBW infants. To our knowledge, there have been no other reports of repeated RCV measurements in the same VLBW infants during the first weeks of life. The fall in $\mathrm{RCV} / \mathrm{kg}$ parallels the fall in hemoglobin concentration seen in preterm infants during the first several months (17).

The mean volume of phlebotomy losses for the 12 infants with two measurements of RCV, $29.2 \mathrm{ml}$ of RBCs over $\sim 40 \mathrm{~d}$, is equivalent to $\sim 0.7 \mathrm{ml} / \mathrm{kg} / \mathrm{d}$. This figure is similar to other 
Table 2. RBC balance in VLBW infants

\begin{tabular}{|c|c|c|c|c|c|c|c|c|c|}
\hline Patient number & $\begin{array}{l}\mathrm{RCV}_{1} \\
(\mathrm{ml})\end{array}$ & $\begin{array}{l}\text { Weight at } \\
\mathrm{RCV}_{1}(\mathrm{~kg})\end{array}$ & $\begin{array}{c}\text { Hct at } \\
\operatorname{RCV}_{1}(\%)\end{array}$ & $\begin{array}{l}\mathrm{RCV}_{2} \\
(\mathrm{ml})\end{array}$ & $\begin{array}{l}\text { Weight at } \\
\mathrm{RCV}_{2}(\mathrm{~kg})\end{array}$ & $\begin{array}{c}\text { Hct at } \\
\operatorname{RCV}_{2}(\%)\end{array}$ & $\begin{array}{l}\text { Phlebotomy } \\
\text { RBC losses (ml) }\end{array}$ & $\begin{array}{c}\text { Transfused } \\
\text { RBCs (ml) }\end{array}$ & $\begin{array}{l}\text { P-D } \\
(\mathrm{ml})\end{array}$ \\
\hline 1 & 24.0 & 0.99 & 52 & 33.4 & 1.24 & 36 & 26.8 & 60.8 & -24.6 \\
\hline 3 & 38.6 & 1.14 & 66 & 26.1 & 1.53 & 36 & 24.3 & 31.3 & -19.5 \\
\hline 4 & 61.4 & 1.31 & 59 & 26.1 & 1.40 & 43 & 46.4 & 64.1 & -53.0 \\
\hline 7 & 36.0 & 1.00 & 70 & 19.4 & 1.13 & 30 & 21.6 & 12.0 & -7.0 \\
\hline 8 & 45.8 & 0.78 & 66 & 15.4 & 1.10 & 34 & 32.8 & 17.4 & -15.0 \\
\hline 9 & 26.1 & 0.96 & 43 & 24.3 & 1.04 & 44 & 49.1 & 33.5 & $+13.8^{\mathrm{a}}$ \\
\hline 10 & 36.2 & 0.92 & 50 & 28.3 & 1.46 & 32 & 24.5 & 16.7 & -0.1 \\
\hline SD & 11.4 & 0.16 & 10 & 7.1 & 0.23 & 6 & 13.2 & 25.9 & 18.7 \\
\hline
\end{tabular}

All volumes are expressed as $\mathrm{ml}$ of RBCs.

Hct, hematocrit; P-D, RBC production minus destruction in vivo (net RBC production).

aThis patient also had five exchange transfusions, with a total of $320.4 \mathrm{ml}$ of RBCs transfused and $287.7 \mathrm{ml}$ of RBCs removed; including these volumes, the net RBC production for this patient (P-D) was $-18.9 \mathrm{ml}$.

reports (18-21), including some from recent years (22). At the time of our study, microanalytical techniques were already in use in the clinical laboratories at McMaster University Medical Centre (Hamilton, Ontario, Canada).

The volumes of RBCs lost by phlebotomy and gained by transfusion were roughly equal in magnitude to the initial RCV. This means that the removal of RBCs by phlebotomy and their replacement by transfusion produces a volume of RBC turnover equivalent to what would occur in a single-volume exchange transfusion but over a period of $6 \mathrm{wk}$.

Our method of measuring RCV used a radioactive RBC label, ${ }^{51} \mathrm{Cr}$. At the time these studies were conducted, research using radioisotopes in infants was an accepted practice. Saenger and Kereiakes (23) suggested 5,000 millirads (50 mSv) as an upper limit for exposure of newborn infants to $\gamma$ irradiation for research purposes. The dose required for our RCV method, $0.16 \mathrm{mSv}$, was far below this limit. Nevertheless, the use of radioactive substances for research in infants would be considered ethically unacceptable in the 21 st century. Fortunately, biotin has been developed as a safe, nonradioactive RBC label for studies of RCV and RBC survival in infants $(10,11,14,24,25)$, allowing continued research in this important area.

To our knowledge, even $36 \mathrm{y}$ after the studies were done, this is still the first report documenting the change in RCV that occurs in individual VLBW infants during the first weeks of life, when anemia of prematurity is evolving. As such, our study shows by direct measurement of RCV that the postnatal fall in hemoglobin and hematocrit in VLBW infants results not only from a decrease in RCV expressed in $\mathrm{ml} / \mathrm{kg}$ but also, in most patients, from a decrease in the absolute RCV expressed in $\mathrm{ml}$.

\section{METHODS}

The subjects were born weighing less than $1.5 \mathrm{~kg}$ and were patients in the McMaster University Neonatal Unit between October 1976 and June 1977.

All infants had at least one measurement of their circulating RCV during the first $5 \mathrm{~d}$ of life, and a convenience sample of these infants had their RCV measured again at $6 \mathrm{wk}$ of age, a time that corresponds to the usual nadir in hemoglobin concentration resulting from anemia of prematurity (17). For these infants, the volume of blood removed for laboratory monitoring, including blood incidentally wasted during phlebotomy, and the volume of blood given as transfusions were determined and recorded.

The method of determining RCV was a scaled-down adaptation of a technique that was well established in adults (26). One milliliter of the infant's blood was collected by venipuncture or from an indwelling umbilical catheter and then injected into a vial containing $0.25 \mathrm{ml}$ of acid-citrate-dextrose anticoagulant. The sample was centrifuged, and the plasma was discarded. The red cells were incubated with 2 microcuries of ${ }^{51} \mathrm{Cr}$ sodium chromate at room temperature for $20 \mathrm{~min}$, then washed twice with $2 \mathrm{ml}$ of normal saline, and resuspended in $1 \mathrm{ml}$ of saline. The labeling efficiency was determined to be greater than $95 \%$.

The labeled cells were reinjected through the umbilical catheter, if present, or a 25-gauge butterfly needle. Fifteen and $30 \mathrm{~min}$ after the reinjection of the labeled RBCs, $0.1-\mathrm{ml}$ blood samples were obtained by heel prick using heparinized microhematocrit tubes. The hematocrit was determined, and the sample was transferred quantitatively into a counting tube. The weight of the sample of blood was determined, and $1 \mathrm{ml}$ of water was added to the counting tube to lyse the cells and reduce the counting errors arising from inhomogeneous samples. Each sample was counted for $30 \mathrm{~min}$; the counting error was less than $1 \%$. The mean difference in RCV calculated from the 15and 30 -min samples was $3.5 \%$. Two infants had their RCV measured twice within $4 \mathrm{~h}$ with separate injections of ${ }^{51} \mathrm{Cr}$. The mean difference in RCV calculated from the two injections was $5 \%$.

Injection of 2 microcuries of ${ }^{51} \mathrm{Cr}$ into a 1-kg infant provided an effective dose of $\sim 0.16 \mathrm{mSv}$. The International Commission on Radiological Protection recommends that the total effective dose from a procedure be compared with the radiation exposure from natural background sources such as the sun, outer space, and radioactive materials found in the earth's air and soil, which is $3 \mathrm{mSv}$ per year (27). 
For the infants whose RCV was measured twice, records were kept of the volume of blood removed for laboratory analyses and the volume of blood transfused between the two RCV measurements. These volumes of blood were converted to volumes of RBCs using the infant's hematocrit for the blood removed and the hematocrit of the transfused blood product. In addition, in six infants, all materials containing any of the patient's blood, which would normally be discarded-such as needles, syringes, gauze pads, cotton balls, tissues, and bandages - were collected in a bag attached to the bedside, and the volume of blood in these materials was determined by radioactive counting.

The net $\mathrm{RBC}$ production (production minus destruction in vivo, designated as P-D) was calculated as $\mathrm{RCV}_{2}-\mathrm{RCV}_{1}+S-T$, where $\mathrm{RCV}_{2}$ is the RCV at $6 \mathrm{wk}, \mathrm{RCV}_{1}$ is the initial RCV, $S$ is the volume of RBCs sampled by phlebotomy for laboratory analysis between $\mathrm{RCV}_{1}$ and $\mathrm{RCV}_{2}$, and $T$ is the volume of RBCs transfused between the RCV measurements. Descriptive statistics were calculated for the RCV measurements and RBC volumes removed and transfused. RCV was expressed both as $\mathrm{ml}$ and as $\mathrm{ml} / \mathrm{kg}$. The decrease in RCV during the first $6 \mathrm{wk}$ was tested for significance using the Wilcoxon signed-rank test.

The study was approved by the McMaster University institutional review board. Informed consent for study participation was obtained in writing from one or both parents of each patient.

\section{ACKNOWLEDGMENTS}

Red cell volume measurements from some of the patients included in this series were also included in a previous non-peer-reviewed publication (Blanchette VS, Zipursky A. Clin Perinatol. 1984;11:489), which did not address the central theme of this report, the change in red cell volume over time and the red cell balance during evolution of anemia of prematurity.

\section{STATEMENT OF FINANCIAL SUPPORT}

This research was supported by the March of Dimes Foundation and the Ontario Ministry of Health.

Disclosure: The authors declared no conflict of interest.

\section{REFERENCES}

1. Mollison PL, Veall N, Cutbush M. Red cell and plasma volume in newborn infants. Arch Dis Child 1950;25:242-53.

2. Bratteby LE. Studies on erythro-kinetics in infancy. VIII. Mixing, disappearance rates and distribution volume of labelled erythrocytes and plasma proteins in early infancy. Acta Soc Med Ups 1967;72:249-71.

3. Bratteby LE. Studies on erythro-kinetics in infancy. IX. Prediction of red cell volume from venous haematocrit in early infancy. Acta Paediatr Scand 1968;57:125-31.

4. Bratteby LE. Studies on erythro-kinetics in infancy. X. Red cell volume of newborn infants in relation to gestational age. Acta Paediatr Scand 1968;57:132-6.

5. Bratteby LE. Studies on erythro-kinetics in infancy. XI. The change in circulating red cell volume during the first five months of life. Acta Paediatr Scand 1968;57:215-24.

6. Phibbs RH, Johnson P, Tooley WH. Cardiorespiratory status of erythroblastotic newborn infants. II. Blood volume, hematocrit, and serum albumin concentration in relation to hydrops fetalis. Pediatrics 1974;53:13-23.

7. Faxelius G, Raye J, Gutberlet R, et al. Red cell volume measurements and acute blood loss in high-risk newborn infants. J Pediatr 1977;90:273-81.
8. Linderkamp O, Betke K, Fendel H, Klemm J, Lorenzen K, Riegel KP. Tc-99m-labeled red blood cells for the measurement of red cell mass in newborn infants: concise communication. J Nucl Med 1980;21: $637-40$.

9. Cavill I, Trevett D, Fisher J, Hoy T. The measurement of the total volume of red cells in man: a non-radioactive approach using biotin. $\mathrm{Br} J$ Haematol 1988;70:491-3.

10. Hudson IRB, Cavill IAJ, Cooke A, et al. Biotin labeling of red cells in the measurement of red cell volume in preterm infants. Pediatr Res 1990;28:199-202.

11. Mock DM, Bell EF, Lankford GL, Widness JA. Hematocrit correlates well with circulating red blood cell volume in very low birth weight infants. Pediatr Res 2001;50:525-31.

12. Phillips HM, Holland BM, Abdel-Moiz A, et al. Determination of red-cell mass in assessment and management of anaemia in babies needing blood transfusion. Lancet 1986;1:882-4.

13. Wardle SP, Yoxall CW, Crawley E, Weindling AM. Peripheral oxygenation and anemia in preterm babies. Pediatr Res 1998;44:125-31.

14. Nalbant D, Bhandary P, Matthews NI, et al. Comparison of multiple red cell volume methods performed concurrently in premature infants following allogeneic transfusion. Pediatr Res 2013;74:592-600.

15. Fisher J, Matthes JWA, Wynn R, et al. Determination of red cell volume in infants needing blood transfusion. Transfus Med 2000;10:219-24.

16. Usher RH, Saigal S, O'Neil A, Surainder Y, Chua L-B. Estimation of red blood cell volume in premature infants with and without respiratory distress syndrome. Biol Neonate 1975;26:241-8.

17. Dallman PR. Anemia of prematurity. Annu Rev Med 1981;32:143-60.

18. Kakaiya RM, Morrison FS, Rawson JE, Lotz LL, Martin JW. Pedi-pack transfusion in a newborn intensive care unit. Transfusion 1979;19: $19-24$.

19. Nexø E, Christensen NC, Olesen H. Volume of blood removed for analytical purposes during hospitalization of low-birthweight infants. Clin Chem 1981;27:759-61.

20. Obladen M, Sachsenweger M, Stahnke M. Blood sampling in very low birth weight infants receiving different levels of intensive care. Eur J Pediatr 1988;147:399-404.

21. Lin JC, Strauss RG, Kulhavy JC, et al. Phlebotomy overdraw in the neonatal intensive care nursery. Pediatrics 2000;106:E19.

22. Freise KJ, Widness JA, Veng-Pedersen P. Erythropoietic response to endogenous erythropoietin in premature very low birth weight infants. J Pharmacol Exp Ther 2010;332:229-37.

23. Saenger EL, Kereiakes JG. The safe tracer dose in medical investigation. Prog At Med 1971;3:139-65.

24. Strauss RG, Mock DM, Johnson K, et al. Circulating RBC volume, measured with biotinylated RBCs, is superior to the Hct to document the hematologic effects of delayed versus immediate umbilical cord clamping in preterm neonates. Transfusion 2003;43:1168-72.

25. Aladangady N, Aitchison TC, Beckett C, Holland BM, Kyle BM, Wardrop CAJ. Is it possible to predict the blood volume of a sick preterm infant? Arch Dis Child Fetal Neonatal Ed 2004;89:F344-7.

26. International Committee for Standardization in Hematology (ICHS). Panel on Diagnostic Applications of Radioisotopes in Haematology. Standard techniques for the measurement of red-cell and plasma volume. Br J Haematol 1973;25:801-14.

27. International Commission on Radiological Protection Committee 3. Radiation and your patient: a guide for medical practitioners. Ann ICRP 2001:31:5-31. 